\title{
ВАЛІДАЦІЯ МЕТОДИКИ КІЛЬКІСНОГО ВИЗНАЧЕННЯ КРОМОГЛІКАТУ НАТРІЮ В ОЧНИХ КРАПЛЯХ ПРОТИАЛЕРГІЙНОї ДІї
}

\author{
(С). Г. Фетісова \\ Національний фрармацевтичний університет, Харків
}

\begin{abstract}
Резюме: у статті розглянуто результати валідації методики кількісного визначення кромоглікату натрію методом абсорбції спектрофотометрії в УФ-області відповідно до вимог ДФУ. Встановлено відповідність методики критеріям прийнятності для допусків змісту $\pm 5 \%$ за валідаційними характеристиками: специфічність, правильність, прецизійність (збіжність) і лінійність. За результатами проведення валідації методики кількісного визначення кромоглікату натрію обґрунтовано і експериментально доведено, що ця методика дає достовірні результати, може бути коректно відтворена і придатна для контролю якості препарату «Кромоглікат», 2 \% очних краплі на різних етапах його життєвого циклу.
\end{abstract}

Ключові слова: кромоглікат натрію, очні краплі, кількісне визначення, спектрофотометрія в УФ-області, валідація.

Вступ. На даний час у процесі орармацевтичної розробки лікарських засобів (ЛЗ), а також на усіх етапах їх життєвого циклу важливіше значення набуває аналітичний супровід експериментів і оцінка аналітичних методик, необхідних для контролю процесу і продукції. Розробка і валідація методик аналізу конкретних ЛЗ у формі очних крапель має свою специфіку, що пов'язано з наявністю в їх складі комбінації АФІ і допоміжних речовин, які розрізняються за фрізикохімічними властивостями та виконують різні фрункції для забезпечення необхідних показників якості. Для отримання відтворюваних результатів потрібна стандартизація методів аналізу, умов їх проведення, реактивів і стандартних зразків, що обов'язково при виконанні фрармацевтичної розробки і складанні реєстраційного досьє на ЛЗ. Відповідно до вимог ДФУ усі методики контролю якості ЛЗ, використовувані для офіційного аналізу, мають бути валідовані, тобто експериментально доведено, що методика придатна для вирішення передбачуваних завдань [1]. Нами розроблені очні краплі протиалергійної дії на основі кромоглікату натрію (KH) та методика кількісного визначення КН в лікарському препараті (ЛП) методом абсорбційної спектрофротометрії в УФ-області. Мета роботи полягала у визначенні валідаційних параметрів розробленої методики і експериментальному доказі того, що ця методика даватиме відтворювані та достовірні результати при проведенні тесту «Кількісне визначення».

Методи дослідження. Об'єкт дослідження: ЛП у формі очних крапель на основі КН в терапевтичній концентрації 2 \%. Для приготування використовували КН, якій відповідає вимогам Європейської фрармакопеї [2] виробництва фрірми «Fermion» (Фінляндія). Методи дослідження: абсорбційної спектрофотоме- трія в УФ-області (ДФУ, 2.2.25) [3]. Аналітичне обладнання: спектрофотометр UV-VIS HP 8453 фрірми «Hewlett Packard» (США), лабораторні електронні ваги BA-210S фрірми «Sartorius» (Німеччина), мірний посуд класу точності А. Статистичну обробку результатів хімічного експерименту проводили відповідно до вимог ДФУ [1].

Результати й обговорення. Експериментально встановлено, що КН у фосфратному буферному розчині рН 7,4 в області від 290 до 370 нм має максимум поглинання при довжині хвилі $(327+2)$ нм. На підставі цих даних для кількісного визначення КН в очних краплях вибраний метод абсорбційної спектрофотометрії в УФ-області (ДФУ, 2.2.25) [3]. Відповідно до розробленої методики на спектрофотометрі паралельно вимірюють оптичну густину випробовуваного розчину і розчину порівняння при довжині хвилі 327 нм в кюветі з товщиною шару 10 мм, використовуючи як компенсаційний розчин фосоратний буферний розчин $\mathrm{pH}$ 7,4 Р. Як розчин порівняння використовують розчин РСО КН у фросоратному буфрерному розчині $\mathrm{pH}$ 7,4 Р. Ґрунтуючись на результатах аналізу і відповідно до вимог, які висувають до вмісту діючих речовин у ЛП [4], вміст КН в 1 мл регламентований в межах від 0,018 г до 0,022 г. Спектри поглинання випробовуваного розчину, розчину порівняння і розчину «плацебо» наведено на рисунку 1.

Валідація розробленої методики кількісного визначення КН проведена відповідно до вимог ДФУ за основними валідаційними характеристиками: специорічність, правильність, прецизійність (збіжність), лінійність, діапазон застосування, внутрішньолабораторна прецизійність. Також проведений розрахунок прогнозованої повної невизначеності результатів аналізу.

ISSN 2312-0967. Pharmaceutical review. 2015. № 2 


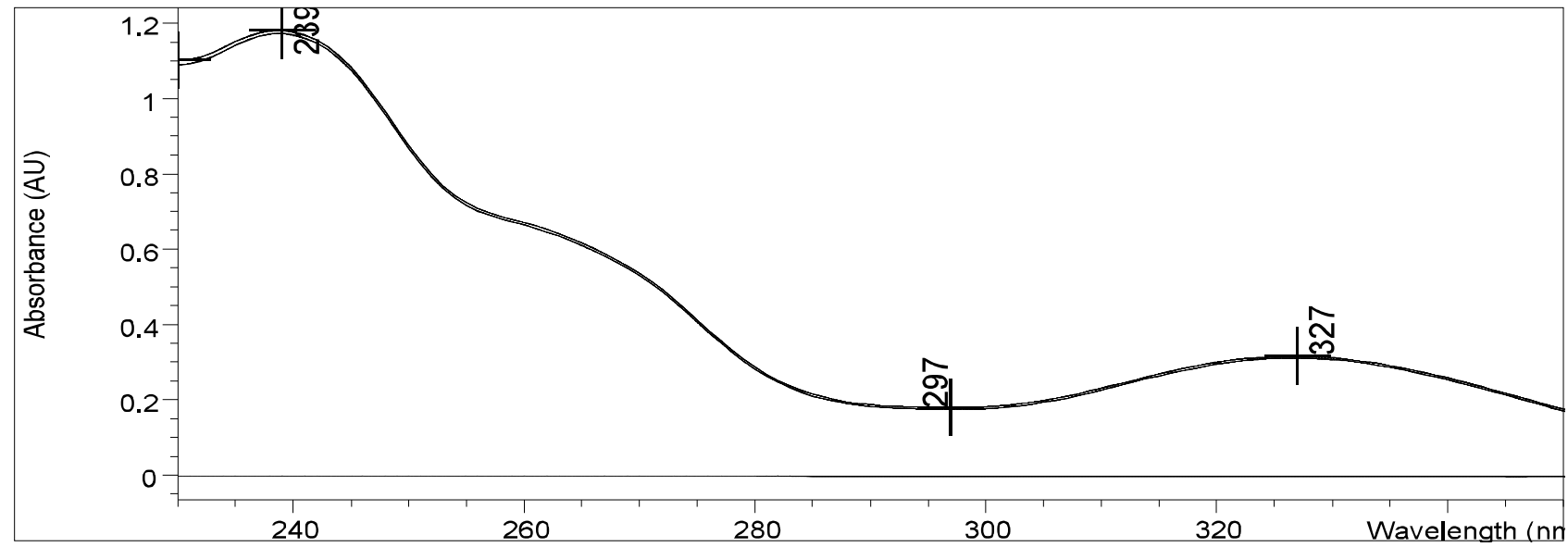

Рис. 1. УФ-спектри розчину порівняння, випробовуваного розчину і розчину «плацебо» для визначення КН.

Перевірка лінійності, правильності і збіжності методики проведена методом «введено-знайдено». Враховуючи, що допустима концентрація ЛВ при виробництві знаходиться в межах $\pm 5 \%$ від номінальних значень, а в процесі зберігання лП - $10 \%$ [4], згідно з вимогами ДФУ діапазон концентрацій для дослідження лінійності, правильності і збіжності склав від 80 до 120 \%, з кроком в 5 \% [1]. Критерії прийнятності розраховані для B=5 , отже, максимальна невизначеність аналізу не повинна перевищувати 1,6 \% [5]. Результати визначення КН в модельних розчинах в області 16-24 мкг/мл, представлені в таблиці 1. На рисунку 2 наведено залежність оптичної густини від концентрації КН в нормалізованих координатах, яка має лінійний характер.

3 даних таблиці 1 видно, що методика характеризується достатньою збіжністю та правильністю в усьому діапазоні досліджуваних концентрацій. Знайдене значення відносного довірчого інтервалу величини $\left(\Delta_{z}=1,23 \%\right)$ менше критичного значення для збіжності результатів (1,6 \%). Систематична погрішність методики $\delta=0,04 \%<0,41 €$ практично незначущою, тобто виконується критерій незначущості систематичної погрішності методики.

У таблиці 2 наведено результати розрахунків параметрів лінійної залежності $\mathrm{Yi}=\mathrm{b}^{\star} \mathrm{Xi+a}$ для $\mathrm{KH}$, проведені методом найменших квадратів за даними таблиці 1.

3 таблиці 2 видно, що виконання вимог до параметрів лінійної залежності підтверджує лінійність методики визначення КН в усьому діапазоні досліджуваних концентрацій. Високе значення коефіцієнта кореляції r=0,99918 задовольняє вимоги критерію прийнятності ( $r=0,99810)$. Таким чином, підтверджена лінійність залежності між взятою і знайденою кількістю КН в усьому діапазоні концентрацій від 80 до $120 \%$ відносно номінальної кількості КН в ЛП, що беруть для аналізу відповідно до методів контролю якості (МКЯ) на ЛП.

Специфічність методики підтверджується відсутністю впливу фронового поглинання і незначною від-

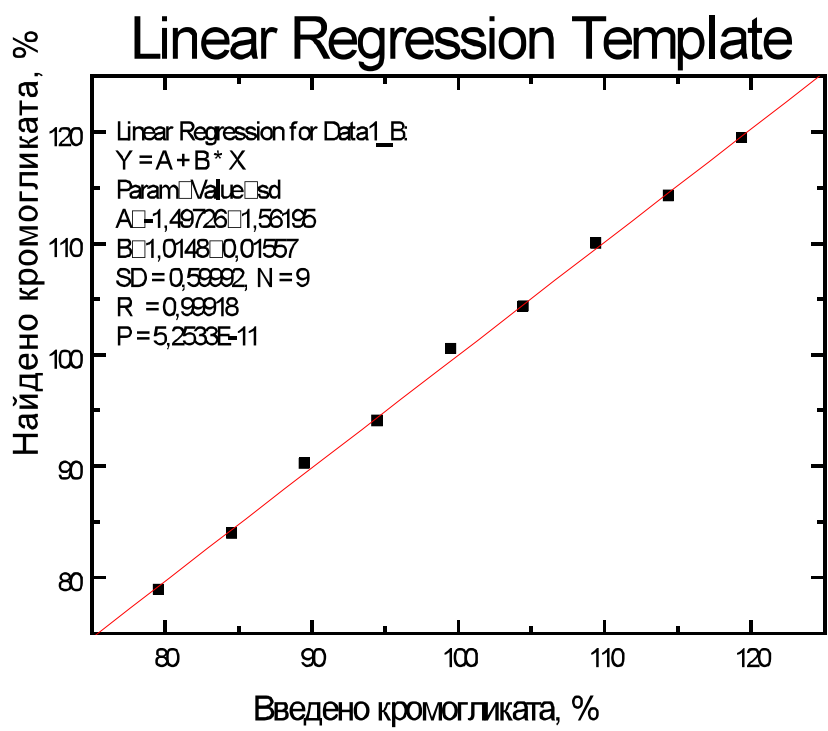

Рис. 2. Лінійна залежність оптичної щільності від концентрації КН в нормалізованих координатах.

носною систематичною похибкою $\left(\delta_{\text {noise }}=0,12 \%\right)$, яка вноситися допоміжними речовинами і можливими продуктами розкладання. Дослідження показали, що у випадку $\mathrm{B}=5 \%$ не виконується співвідношення $\delta_{\text {noise }}=\delta_{\text {imp }}+\delta_{\text {placebo }}(0,12 \%+0,5 \%) \leq \delta_{\text {noise reop }}(0,51 \%)$, але виконується у випадку $\mathrm{B}=10 \%$. Співвідношення $\delta_{\text {placebo }} \leq 0,033 \times \mathrm{B}=0,165 \%$ виконується. Таким чином, фронове поглинання «плацебо» $є$ незначимим, методика характеризується достатньою специорічністю, модельні розчини можливо готувати без використання «плацебо».

Дослідження внутрішньолабораторної прецизійність проводили на 6 пробах одного зразка ЛП в 3 різні дні різними аналітиками з використанням різного мірного посуду. Результати перевірки внутрішньолабораторної прецизійності кількісного визначення $\mathrm{KH}$, наведені в таблиці 3, показують, що величина

ISSN 2312-0967. Фармацевтичний часопис. 2015. № 2 
Таблиця 1. Результати аналізу модельних сумішей та їх статистична обробка для кількісного визначення КН

\begin{tabular}{|c|c|c|c|c|}
\hline $\begin{array}{l}\text { № } \\
\text { модельного } \\
\text { розчину }\end{array}$ & $\begin{array}{c}\text { Введено в \% до } \\
\text { концентрації розчину } \\
\text { порівняння } \\
\text { (Xi= Ci/Cst, \%) }\end{array}$ & $\begin{array}{l}\text { Середні оптичні } \\
\text { густини (Ai) } \\
\text { (Ast=0,315229) }\end{array}$ & $\begin{array}{c}\text { Знайдено в \% } \\
\text { до концентрації } \\
\text { розчину порівняння } \\
\text { (Yi= Ai/Ast, \%) }\end{array}$ & $\begin{array}{c}\text { Знайдено в \% до } \\
\text { введеного } \\
(\mathrm{Zi}=\mathrm{Yi} / \mathrm{Xi}, \%)\end{array}$ \\
\hline 1 & 79,60 & 0,248579 & 78,86 & 99,10 \\
\hline 2 & 84,58 & 0,264529 & 83,92 & 99,20 \\
\hline 3 & 89,55 & 0,284260 & 90,18 & 100,70 \\
\hline 4 & 94,53 & 0,296418 & 94,03 & 99,50 \\
\hline 5 & 99,55 & 0,316745 & 100,48 & 101,00 \\
\hline 6 & 104,48 & 0,328749 & 104,29 & 99,80 \\
\hline 7 & 109,45 & 0,346671 & 109,97 & 100,50 \\
\hline 8 & 114,43 & 0,360011 & 114,21 & 99,80 \\
\hline 9 & 119,40 & 0,376409 & 119,41 & 100,00 \\
\hline \multicolumn{4}{|c|}{ Середнє, Zср, \% } & 99,96 \\
\hline \multicolumn{4}{|c|}{$R S D_{z}(\%)=\sqrt{\frac{\sum_{i}}{n-1} \times \frac{100}{\bar{Z}}}$} & 0,66 \\
\hline \multicolumn{4}{|c|}{$\begin{array}{l}\text { Відносний довірчий інтервал, } \\
\Delta \%=t(95 \%, n-1) \times R S D_{z}=1,860 \times R S D_{z}, \%\end{array}$} & 1,23 \\
\hline \multicolumn{4}{|c|}{$\begin{array}{l}\text { Критичне значення для збіжності результатів } \Delta_{\text {As }}, \% \\
\text { (гранична невизначеність) }\end{array}$} & 1,6 \\
\hline \multicolumn{4}{|c|}{ Систематична погрішність $\delta$ = |Zcp - 100| } & 0,04 \\
\hline \multicolumn{5}{|c|}{$\begin{array}{l}\text { Критерій незначущості систематичної помилки } \\
\text { Статистична незначущість: }\end{array}$} \\
\hline \multicolumn{4}{|c|}{$\delta \% \leq \Delta_{\bar{Z}}=\frac{\Delta_{\bar{Z}}}{\sqrt{n}}=\frac{\Delta_{\bar{Z}}}{3} 1,23 / 3=0,41(0,04<0,41)$} & Виконується \\
\hline \multicolumn{4}{|c|}{ Загальний висновок про точність методики } & Коректна \\
\hline
\end{tabular}

Таблиця 2. Метрологічні характеристики лінійної залежності для КН

\begin{tabular}{|c|c|c|c|}
\hline Величина & Значення & $\begin{array}{c}\text { Критерій } \\
\text { (для допусків 95,0 }-105,0 \%, g=9)\end{array}$ & Висновок \\
\hline $\mathrm{b}$ & 1,0148 & - & - \\
\hline $\mathrm{S}_{\mathrm{b}}$ & 0,01557 & - & Відповідає \\
\hline $\mathrm{a}$ & $-1,49726$ & 1) $\leq 1,895 \times \mathrm{S}_{\mathrm{a}}=2,96$ & - \\
\hline $\mathrm{S}_{\mathrm{a}}$ & 1,56195 & 2) якщо не виконується 1), то $\leq 2,56$ & Відповідає \\
\hline $\mathrm{S}_{\mathrm{r}}$ & 0,59992 & - & - \\
\hline $\mathrm{r}$ & 0,99918 & $\geq 0,99810$ & . \\
\hline
\end{tabular}

ISSN 2312-0967. Pharmaceutical review. 2015. № 2 
Аналіз лікарських препаратів

Analysis of drugs

Таблиця 3. Результати перевірки внутрішньолабораторної прецизійності визначення КН

\begin{tabular}{|c|c|c|c|}
\hline \multirow{2}{*}{ Величина } & \multicolumn{3}{|c|}{ Значення Zi, \% } \\
\hline & 1 дослід & 2 дослід & 3 дослід \\
\hline Середнє $\bar{Z}(\%), \bar{Z}(\%)=\frac{1}{6} \sum Z_{i}$ & 100,71 & 100,19 & 100,99 \\
\hline Об'єднане середнє & \multicolumn{3}{|c|}{100,63} \\
\hline $\begin{array}{l}\text { Відносне стандартне відхилення, } \operatorname{RSD}_{z}(\%), \\
R S D_{Z}=\sqrt{\frac{\sum\left(Z_{i}-\bar{Z}\right)^{2}}{8}} \times \frac{100}{\bar{Z}}\end{array}$ & \multicolumn{3}{|c|}{0,87} \\
\hline $\begin{array}{l}\text { Відносний довірчий інтервал } \\
\Delta_{\bar{Z}}=t(95 \%, 17) \times \frac{R S D_{Z}}{\sqrt{6}}\end{array}$ & \multicolumn{3}{|c|}{$1.74 \times 0.87 / \sqrt{6}=0,62 \leq 1,6$} \\
\hline $\begin{array}{l}\text { Критичне значення для збіжності результатів } \Delta_{\text {As }} \% \\
\text { (гранична невизначеність) }\end{array}$ & \multicolumn{3}{|c|}{1,6} \\
\hline
\end{tabular}

відносного довірчого інтервалу для шести паралельних вимірів 18 проб однієї серії очних крапель $\left(\Delta_{z}=0,62 \%\right)$ задовольняє критерію прийнятності при $\mathrm{B}=5,0 \%(\leq 1,6 \%)$.

Для підтвердження коректності методики при відтворенні в інших лабораторіях проведений прогноз повної невизначеності методики $\left(\Delta_{\mathrm{As}}\right)$, яка включає невизначеність пробопідготовки $\left(\Delta_{\mathrm{SP}}\right)$ і невизначеність кінцевої аналітичної операції $\left(\Delta_{\mathrm{FAO}}\right)$ та не повинна перевищувати максимально допустиму невизначеність результатів аналізу для допусків вмісту $\pm 5 \%$ $-\max \Delta_{\mathrm{As}} \leq 1,6 \%$.

Розрахунок сумарної невизначеності пробопідготовки для тесту «Кількісне визначення» проведений з розрахункових фрормул МКя з використанням підходу до допустимої невизначеності мірного посуду [1], $\Delta_{\mathrm{Sp}}=1,18 \%$. Для прогнозу невизначеності кінцевої аналітичної операції використовували відносне стандартне відхилення вимірів оптичної густини 3 рандомізацією положення кювет, отримане в міжлабораторному експерименті, $\Delta_{\text {FAO }}=0,52 \%[1,6]$.

Сумарна невизначеність аналізу з урахуванням $\delta_{\text {noise }}=0,62 \%$ склала:

$$
\Delta_{A S}, \%=\sqrt{0,62^{2}+1,18^{2}+0,52^{2}}=1,42 \% \leq \Delta_{\text {Asteop }}=
$$
$1,6 \%$.
Таким чином, повна прогнозована невизначеність результатів для тесту «Кількісне визначення» КН не більше критичнішого значення (1,6 \%), тобто методика даватиме коректні результати в інших лабораторіях за цим показником.

Висновки. 1. Проведена валідація методики кількісного визначення КН методом абсорбційної спектрофотометрії в УФ-області відповідно до вимог ДФУ.

2. Встановлена відповідність критеріям прийнятності для допусків вмісту $\pm 5 \%$ для валідаційних характеристик: специфічність, правильність, прецизійність і лінійність.

3. Для підтвердження коректності методики при відтворенні в інших лабораторіях встановлено, що повна прогнозована невизначеність результатів аналізів не перевищує критичне значення невизначеності методик.

4. За результатами проведення валідації методики кількісного визначення КН обґрунтовано і експериментально доведено, що ця методика дає достовірні результати, може бути коректно відтворена і придатна для контролю якості ЛП у формі очних крапель на основі КН на різних етапах його життєвого циклу.

ISSN 2312-0967. Фармацевтичний часопис. 2015. № 2 


\section{Література}

1. Державна фрармакопея України / Державне підприємство «Науково-експертний фрармакопейний центр». - 1-е вид. - Доп. 2. - Х., 2008. - 620 с.

2. European Pharmacopoeia. - 7-th ed. - Strasbourg: European Directorate for the Quality of Medicines, 2009. $-3357 p$.

3. Державна фрармакопея України. / Державне підприємство «Науково-експертний фармакопейний центр. - 1-е вид. - Харків : РІРЕГ, 2001. - 556 с.

4. Руководство 42-3.4:2004. Руководства по качеству. Лекарственные средства. Производство готовых лекарственных средств / [Н. Ляпунов, В. Георгиевский, Е. Безуглая и др.]. - Киев : Морион, 2004. - 12 с.

5. Аналитическая химия в создании, стандартизации и контроле качества лекарственных средств / под ред. член-кор. НАН Украины В. П. Георгиевского. - Харьков : Изд. «НТМТ», 2011 г. Т. 3. - 520 с.

6. Руководство по валидации методик анализа лекарственных средств / под ред. Н.В.Юргеля, А. Л. Младенцева, А. В. Бурдейна и др.; разработчики В. Л. Багирова, А. И. Гризодуб, Т. Х. Чибиляев и др. М. : Фармацевтическая промышленность, 2007. - 58 с.

\title{
ВАЛИДАЦИЯ МЕТОДИКИ КОЛИЧЕСТВЕННОГО ОПРЕДЕЛЕНИЯ КРОМОГЛИКАТА НАТРИЯ В ГЛАЗНЫХ КАПЛЯХ ПРОТИВОАЛЛЕРГИЧЕСКОГО ДЕЙСТВИЯ
}

\author{
Е. Г. Фетисова \\ Национальный фрармацевтический университет, Харьков
}

Резюме: в статье рассмотрены результаты валидации методики количественного определения КН методом абсорбционной спектрофотомерии в УФ-области в соответствии с требованиями ГФУ. Установлено соответствие методики критериям приемлемости для допусков содержания $\pm 5 \%$ по валидационным характеристикам: специфичность, правильность, прецизионность (сходимость) и линейность. По результатам проведения валидации методики количественного определения КН обосновано и экспериментально доказано, что данная методика даёт достоверные результаты, может быть корректно воспроизведена и пригодна для контроля качества препарата Кромогликат, 2 \% глазные капли на различных этапах его жизненного цикла.

Ключевые слова: кромогликат натрия, глазные капли, количественное определение, спектрофотомерия в УФобласти, валидация.

\section{VALIDATION STUDIES OF CROMOGLICATE SODIUM ASSAY AT EYE DROPS WITH ANTIALLERGIC ACTION}

\section{O. H. Fetisova}

\section{National University of Pharmacy, Kharkiv}

Summary: the article adduces the results of validation studies of cromoglicate sodium assay by the spectrophotometric method in accordance with the requirements of the State Pharmacopoeia of Ukraine. For the test it has been established accordance to specified acceptance criteria for the assay limits $\pm 5 \%$ by the validation parameters: specificity, linearity, precision (precision), accuracy within the using range (80-120\% of the nominal contents). Based on the results of validation studies it has been substantiated and verified experimentally that the test can make reliable results, can be correctly reproduced and be suitable for quality control of Cromoglicate, $2 \%$ eye drops during differing stage of product lifecycle.

Key words: cromoglicate sodium, eye drops, assay, absorption spectrophotometry at ultraviolet, validation. 